\title{
Bud Blight of Rhododendron Trees Caused by Pycnostysanus azaleae
}

\author{
Shigeru KaneKo*, Yoshinori YokozaWA* and Takanori Kubono*
}

Key words: Pycnostysanus azaleae, Rhododendron, bud blight.

During the past 2-3 years it has been noted that Rhododendron japonicum growing on the Appi-kogen (tableland) (Appi-dake national forest, Ashiro-cho, Iwate Pref.) did not bloom fully. The Rhododendron trees grow naturally on the tableland $(800-1,000 \mathrm{~m}$ above sea level), and severe damage was observed through $c a .8$ ha. We investigated this occurrence, and found that the major cause was bud blight caused by Pycnostysanus azaleae (Pk.) Mason (Deuteromycotina-Hyphomycetes), which has not been recorded previously in Japan. This paper reports the results of isolation and inoculation experiments and describes the symptoms and signs of the disease and the morphology of the causal fungus.

Symptoms and signs of the disease. The first symptom appeared in autumn as necrosis of the scale bases of new flower buds. The color of the whole flower bud then became brown by winter. During May to June of the next year, black hair-like synnemata (Figs. 1, 2) of a fungus appeared on the overwintered blighted flower buds. The synnemata were also observed on older flower buds and twigs with blighted buds throughout spring to autumn. The synnemata were rarely observed on necrotic spots on living leaves. After rainfall or under conditions of high humidity, droplets including numerous conidia exuded from the top of synnemata (Figs. 3, 4). The blighted flower bud did not bloom. In severe cases, $90 \%$ of the flower buds of a shrub were damaged.

Isolation and culture of the fungus. The isolation experiment was carried out in September, 1986, from blighted and healthy flower buds and leaves with or without necrotic lesions after sterilizing the surface. A fungus was isolated on PDA medium from $90 \%$ of the blighted buds. It was not isolated from leaves with necrotic lesions.

In culture experiments, many synnemata (Fig. 5) began to appear within 4 days when colonies of the fungus on PDA in test tubes were taken from the tubes and placed in petri dishes under a white fluorescent lamp at $20 \mathrm{C}$. The synnemata were also produced on autoclaved flower buds and leaves of Rhododendron japonicum in test tubes under illumination at $20 \mathrm{C}$ within 60 days after inoculation with colonies. This fungus was also isolated from germinating conidia collected from a synnema formed on a blighted flower bud. No difference was found in morphological characteristics of conidia between those produced on blighted buds in the fields or in cultures.

Morphological characteristics of the fungus. Colonies wooly, olive to dark grayish brown. Synnemata black, $0.5 \sim 2.5 \mathrm{~mm}$ long $\times 250 \sim 500 \mu \mathrm{m}$ wide, head capitate with mass of conidia (Figs. 2 4). Conidiogenous cells terminal, cylindrical to doliiform, brown, $11 \sim 19 \times 5 \sim$ $8 \mu \mathrm{m}$ (Figs. 6, 7). Conidia holoblastic, formed in acropetal chains (Figs. 8, 9), each conidium has $1 \sim 3$ conidiogenous loci, globoid to ellipsoidal, pale brown, smooth, one-celled, $6 \sim 11 \times 4 \sim 7$ $\mu \mathrm{m}$. The fungus was identified as Pycnostysanus azaleae ${ }^{1)}$ (Syn. Sporocybe azaleae (Pk.) Saccardo, Briosia azaleae (Pk.) Dearness) based on the morphological characteristics. Sutton ${ }^{1)}$ described the conidiogenous cells of Pycnostysanus azaleae as holoblastic. Primary conidium

\footnotetext{
- Tohoku Research Center, Forestry and Forest Products Research Institute, Shimokuriyagawa, Morioka, Iwate 020-01, Japan 森林総合研究所東北支所

1) Sutton, B. C. (1973). Mycol. Pap. 132: 1-143.
} 
Table 1. Results of inoculation experiments with Pycnostysanus azaleae on the flower buds of Rhododendron japonicum

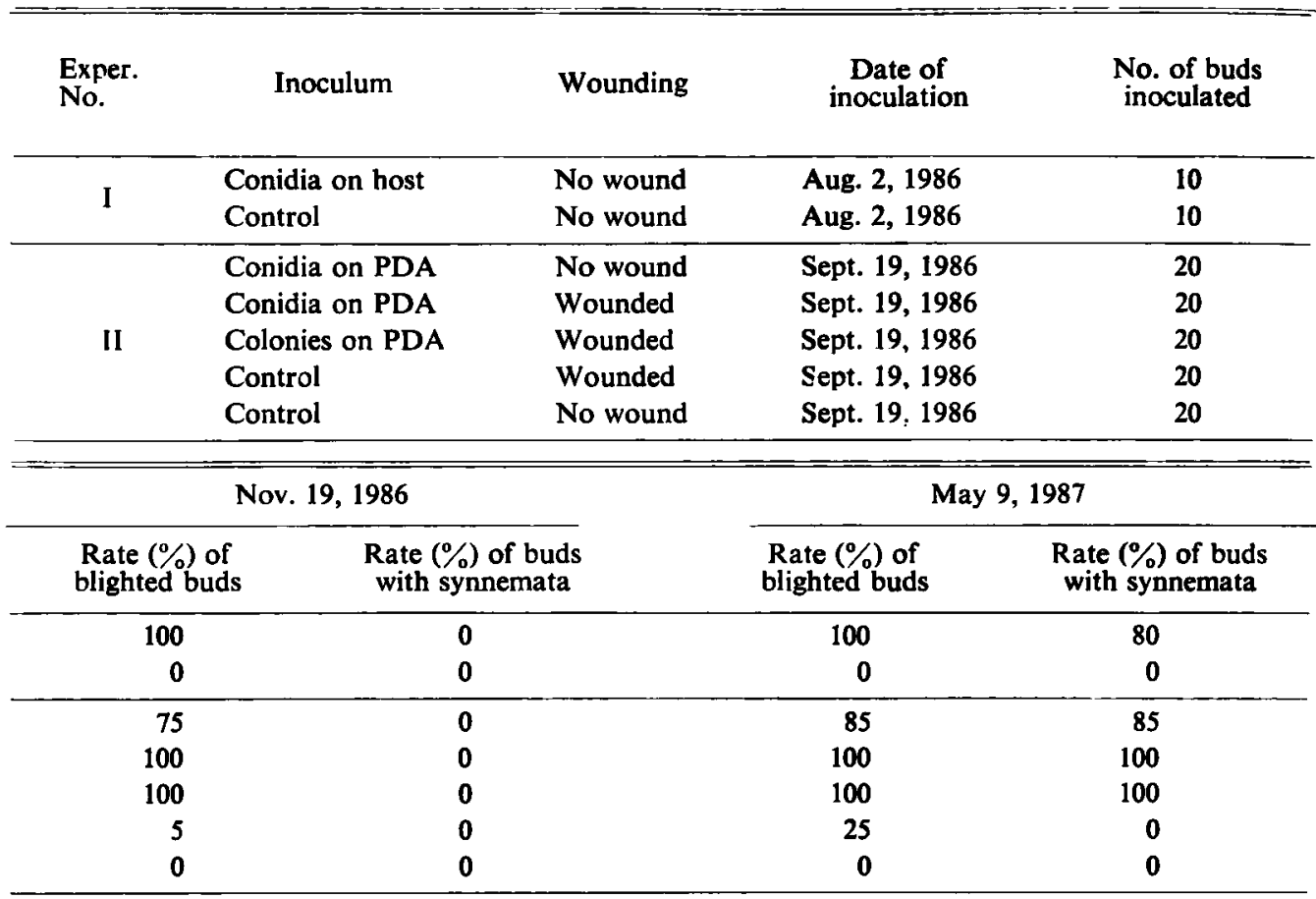

of this species, however, may originate in enteroblastic form (Figs. 6, 7). More precise study will be needed on the ontogeny of codidium development of this species.

Inoculation with the fungus. To demonstrate the pathogenicity of the fungus, inoculation experiments were conducted with Rhododendron japonicum in a chamber and in a nursery of the Institute. When conidial suspension obtained from the colonies on PDA was put on the surface of flower buds and leaves of cut shoots of the Rhododendron in a humid chamber under a white fluorescent lamp at $20 \mathrm{C}$, the flower buds and leaves began to produce necrotic lesions 10 days after inoculation. The inoculated flower buds became brown in color 20 days after inoculation. Synnemata bearing conidia began to appear on the necrotic leaves and flower buds 15 days and 31 days after inoculation, respectively.

Inoculations were also conducted onto the flower buds of planted Rhododendron japonicum shrubs in a nursery of the Institute, using conidia or colonies formed on PDA or conidia from diseased flower buds. The inoculated twigs were covered with polyethylene bags for the first 3 days to maintain high humidity. Under natural conditions, blighted flower buds were often found to be associated with an oviposition hole of a moth, Earias roseifera. Therefore, some buds were inoculated after making a hole of $c a .3 \mathrm{~mm}$ deep with a sterilized needle. The inoculated flower buds became brown by winter of the year. Synnemata appeared on the brown flower buds in May of the following year (Table 1). The fungus was re-isolated from the blighted buds whether synnemata were found or not. These results proved that Pycnostysanus azaleae causes the flower bud blight with no special association with wounds.

This disease of Rhododendron caused by Pycnostysanus azaleae has been recorded in the U.S.A.9), Canada) and England ${ }^{3)}$. Davis ${ }^{4)}$ described the life cycle and pathogenicity of the

2) Schmitz, H. (1920). Phytopathology 10: 273-278. 3) Ellis, M. B. and Ellis J. P. (1985). Microfungi on Land Plants. Croom Helm, London. pp. 222-223. 4) Davis, W. H. (1939). Phytopathology 29: 517-529. 
fungus, and named the disease as bud and twig blight. In our experiments, pathogenicity to twigs has not been proved yet. This is the first record of this disease in Japan.

Through field survey, the same disease has been found in several localities other than the Appi-kogen on Rhododendron japonicum and other Rhododendron species as follows: On $R$. japonicum-Hiraniwa-kogen and Hayasaka-kogen in Iwate Pref.; On $R$. brachycarpum (Hakusanshakunage)-Mt. Iwate and Mt. Hachimantai in Iwate Pref.; On R. kaempferi (Yamatsutsuji)Daiwa-cho in Miyagi Pref. Damage to $R$. brachycarpum and $R$. kaempferi was not as severe as R. japonicum.

We thank Mr. Yukio Takizawa, the head of Forest Protection Division, Kyushu Research Center, Forestry and Forest Products Res. Inst., for identifying Earias roseifera.

和 文摘 要

金子 慗・横沢良憲・寉野高徳：Pycnostysanus azaleae Kよるッッシ類の芽枯病（新称）

岩手県安比高原に自生するレンゲッッシに広く発生した花芽の枯死症状について調査した結果, 主原因は Pycnostysanus azaleae の感染による病害であることが明らかになった。本病は日本では初めて発生が確認 されたものであり, 病徵, 標徽, および病原菌の形態的特徵を記载した。本病の発生は自生するハクサンシ ナクナゲ (岩手県内) およびヤマッッジ（宮城県内）でも認められたが, 被害程度はレンゲッッジに比べ軽 かった。本病の病名として牙枯病 (bud blight) を提唱する。

(Received February 10, 1988) 


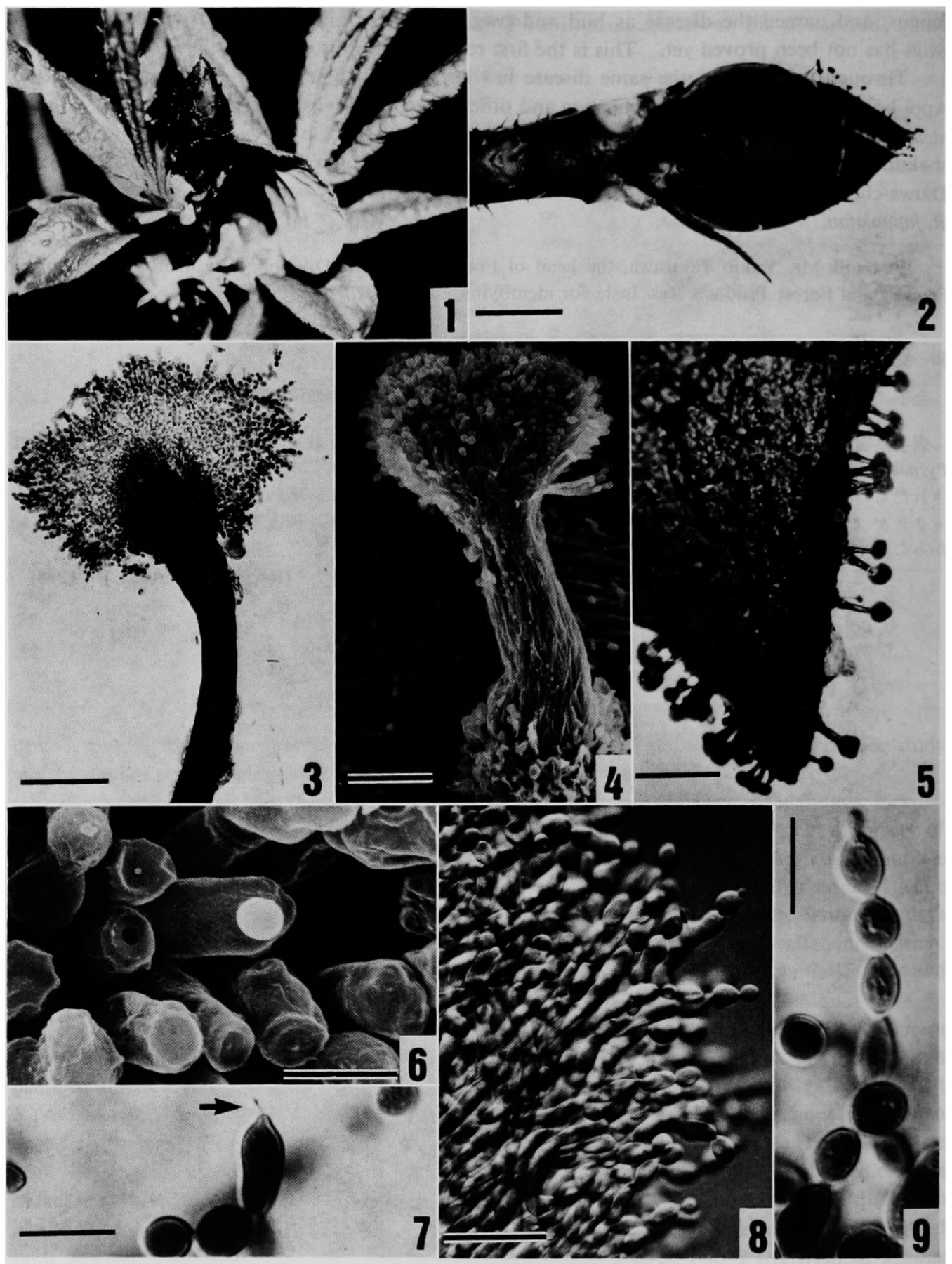

Plate I. Bud blight of Rhododendron japonicum and the causal fungus, Pycnostysanus azaleae.

1, 2. Symptoms and signs. 3. A synnema with conidial chains. 4. A synnema under SEM. 5. Synnemata formed on PDA. 6. Apical part of conidiogenous cells under SEM. 7. A conidiogenous cell producing a conidium (arrow). 8, 9. Conidial chains.

Scales: $2=5 \mathrm{~mm} ; 3=40 \mu \mathrm{m} ; 4=20 \mu \mathrm{m} ; 5=4 \mathrm{~mm} ; 6=3 \mu \mathrm{m} ; 7,9=10 \mu \mathrm{m} ; 8=20 \mu \mathrm{m}$. 